\title{
Kurikulum Terpadu Berbasis Nilai-Nilai Islami
}

\author{
Saehudin \\ STAI Mas'udiyah Sukabumi, Indonesia \\ saehudin@ymail.com
}

Acep Sutisna

STAI Mas'udiyah Sukabumi, Indonesia

acepsutisnasmi2018@gmail.com

DOI: https://doi.org/10.52593/pdg.01.1.01

Naskah diterima: 21 Maret 2020, direvisi: 14 Mei 2020, disetujui: 2 Juni 2020

\begin{abstract}
Abstraksi
Kerangka pemikiran yang melandasi penelitian ini adalah, bahwa Kurikulum terpadu berbasis nilai-nilai islami merupakan salah satu upaya untuk menyeimbangkan antara pendidikan umum dan agama. Sehingga diharapkan peserta didik menjadi pribadi yang integrated yang memilki pengetahuan umum dan agama yang sesuai dan selaras dengan lingkungan sekitarnya. Latar belakang penelitian ini adalah implementasi kurikulum terpadu yang belum berjalan dengan baik, masih ada tumpang tindih antara program satu dengan yang lainnya. Adapun rumusan masalah pada penelitian ini adalah: 1) Bagaimana konsep kurikulum terpadu. 2) Bagaimana implementasi kurikulum terpadu. 3) Bagaimana evaluasi kurikulum terpadu. 4) Apa faktor pendukung dan penghambat kurikulum terpadu. Penelitian ini bertujuan untuk menggambarkan bagaimana efektivitas kurikulum terpadu berbasis nilai-nilai Islami yang dilaksanakan di SMA Pesantren Terpadu Hayatan Thayyibah Kota Sukabumi. Penelitian ini menggunakan pendekatan kualitatif dan metode deskriptif kualitatif. Teknik pengumpulan data dilakukan dengan observasi, wawancara, dan studi dokumentasi. Adapun teknik analisis data dimulai dari pengumpulan data, reduksi data, penyajian data dan penarikan kesimpulan. Sedangkan teknik pemeriksaan data menggunakan uji kredibilitas, transferabilitas, depandabilitas, dan konfirmabilitas. Hasil penelitian ini menunjukkan bahwa: 1) Konsep kurikulum terpadu yang dikembangkan di sekolah ini menggunakan jenis corelated curriculum antara kurikulum nasional (kurtilas) dengan kurikulum kepesantrenan sebagai pengembangan nilai-nilai Islaminya. 2) Implementasi kurikulum terpadu yang dilaksanakan di sekolah ini adalah integrasi kurikulum nasional (kurtilas) terhadap kurikulum kepesantrenan dengan mata pelajaran rumpun keagamaan yang rujukannya diambil dari kitab klasik, namun pada prakteknya menggunakan mata pelajaran terpisah (separate subject curriculum) dengan pengembangan program character building sebagai pembiasaan karakter baik di lingkungan pesantren. 3) Evaluasi kurikulum terpadu dengan melibatkan kepala sekolah melalui supervisi secara berkelanjutan terhadap pelaksanaan pengembangan kurikulum. Sedangkan guru sebagai pelaksana di kelas menggunakan pendekatan proses dan hasil melalui ujian lisan, tulisan, dan observasi terhadap perilaku peserta didik. 4) Faktor pendukungnya adalah manajemen dan fasilitas sekolah yang baik, suasana lingkungan sekolah berbasis pesantren berjalan dengan baik. Faktor penghambatnya adalah kurangnya komunikasi antara pihak sekolah dengan orangtua, struktur kurikulum sekolah gemuk karena jumlah mata pelajaran yang banyak.
\end{abstract}

Kata Kunci : Kurikulum Terpadu, Nilai-Nilai Islami, Lembaga Pendidikan Islam 


\section{A. Pendahuluan}

Kurikulum merupakan seperangkat rencana untuk mencapai tujuan pembelajaran bagi peserta didik. Sehingga, lebih spesifik kurikulum dapat dimaknai sebagi suatu dokumen yang berisi rumusan tujuan, bahan ajar, kegiatan belajar mengajar, jadwal dan evaluasi. Di samping itu, kurikulum juga dapat digambarkan sebagai dokumen tertulis hasil persetujuan bersama antara para penyusun kurikulum dan pemegang kebijakan pendidikan dengan masyarakat yang mencakup lingkup tertentu, baik lingkup secara mikro di suatu sekolah, maupun secara makro di kabupaten/kota, provinsi maupun negara secara keseluruhan. ${ }^{1}$

Kurikulum terpadu merupakan perpaduan antara kurikulum umum yang mengedepankan penguasaan aspek IPTEK (Ilmu Pengetahuan dan Teknologi) dan dipadukan dengan kurikulum kepesantrenan yang berbasis penanaman akhlak sebagai inti nilainya (core ethical values). Dalam pendidikan Islam kurikulum terpadu berupaya untuk menyatukan kembali dikotomi antara pendidikan umum dan agama, sehingga melahirkan pendidikan paripurna yang menyesuaikan diri dengan tuntutan zaman tanpa kehilangan pembinaan pada aspek ruhaninya. Tujuan akhir dari pendidikan Islam menurut Al-Abrasyi dalam Tafsir adalah pembinaan akhlak dan penguasaan ilmu, pengembangan akal dan akhlak, bahagia dunia akhirat serta berakhlak mulia. ${ }^{2}$

Tantangan pendidikan Islam di zaman sekarang adalah menghadapi pertarunganpertarungan ideologi besar dunia (Eropa dan Barat), dan menghadapi berbagai kecenderungan sebagaimana yang diumpamakan Abuddin Nata dalam bukunya Kapita Selekta Pendidikan Islam; Isu-isu Kontemporer tentang Pendidikan Islam, bagaikan terjanagan "badai besar (turbulence) atau tsunami". Selanjutnya menurut Daniel Bell dalam Nata, ${ }^{3}$ dunia di era globalisasi saat ini mempunyai lima tanda kecenderungan, yaitu sebagai berikut: Pertama, terjadinya persaingan bebas dalam dunia pendidikan yang disebabkan oleh kecenderungan integrasi ekonomi. Kedua, terjadinya peningkatan tuntutan dan harapan masyarakat, dimana mereka semakin membutuhkan perlakuan yang adil, demokratis, egaliter, transparan, akuntabel, cepat, tepat, dan professional yang disebabkan oleh kecenderungan pragmentasi politik. Ketiga, kecenderungan penggunaan teknologi canggih (sophisticated technology) khususnya Teknologi Komunikasi dan Informasi (TIK). Keempat, kecenderungan kesalingtergantungan (interdependency), yaitu peran orang lain sangat mempengaruhi, bahkan pemenuhan kebutuhan seseorang sangat dipengaruhi oleh orang lain. Kelima, terjadinya perubahan pola pikir (mindset) masyarakat pengguna pendidikan, dari semula mereka belajar dalam rangka meningkatkan intelektual, moral, fisik, dan psikisnya, menjadi belajar untuk mendapatkan pekerjaan dan penghasilan yang besar yang diakibatkan oleh kecenderungan munculnya kebudayaan baru (new colonization in culture). Tantangan

\footnotetext{
${ }^{1}$ Nana Syaodih Sukmadinata dan R. Ibrahim, Teori Kurikulum dalam Ilmu dan Aplikasi Pendidikan; Bagaian I Ilmu Pendidikan Teoretis, (Bandung: Tim Pengembang Ilmu Pendidikan, FIP UPI, 2009), 94.

${ }^{2}$ Ahmad Tafsir, Ilmu Pendidikan dalam Perspektif Islam, (Bandung: Remaja Rosdakarya, 2010), 49.

${ }^{3}$ Abuddin Nata, Kapita Selekta Pendidikan Islam; Isu-isu Kontemporer tentang Pendidikan Islam, (Jakarta: Rajawali Pers, 2012), 14.
} 
terakhir inilah yang setidaknya (di samping tantangan lain) mengakibatkan ketidakseimbangan antara penguasaan pendidikan umum dan keagamaan di sekolah sebagai imbas dari tujuan pendidikan yang hanya sebatas untuk mendapatkan pekerjaan dan penghasilan saja, cara berfikir inilah yang disebut Tafsir sebagai cara berfikir yang pragmatis. $^{4}$

Lulusan (output) dari proses pendidikan dalam perspektif Islam adalah manusia terbaik (muslim yang kaffah). Cirinya ada tiga, Pertama, berbadan sehat serta kuat, sehat agar tenang dan mampu produktif. Kuat agar dapat berproduksi secara maksimal. Kedua, otaknya cerdas serta pandai, cerdas agar mampu menyelesaikan masalah secara cepat dan tepat. Pandai berarti banyak pengetahuaanya. Ketiga, beriman kuat. Keimanan yang kuat akan memberikan kemampuan mengendalikan diri yang tinggi. ${ }^{5}$ Ketiga ciri manusia terbaik tersebut dipersiapkan untuk menghadapi tantangan bagi para peserta didik ketika sudah kembali ke masyarakat dalam menghadapi kehidupan sehari-hari.

Akibat dari kecenderungan di atas, munculah kesenjangan antara tujuan akhir pendidikan dan realitas lulusan (output) pendidikan di masyarakat, yang pada akhirnya kualitas akhlak yang tidak baik dari para peserta didik tidak sedikit menghiasi pemberitaan baik di media cetak maupun elektronik. Akhlak yang tidak baik pada kalangan peserta didik yang lebih dikenal dengan istilah kenakalan remaja diantaranya adalah perkelahian antar pelajar (tawuran), penyalahgunaan narkoba (narkotika psikotropika dan zat adiktif lainnya), hubungan sex pra nikah (free sex), hingga perbuatan kriminal yang lebih ekstrim. Komnas Perlindungan Anak pada 2012 mencatat 147 kasus tawuran. Dari 147 kasus tersebut sebanyak 82 anak jiwanya sudah melayang menjadi korban, ${ }^{6}$ pada tahun 2013 dari bulan Januari sampai bulan Oktober terdapat 229 kasus tawuran antar pelajar 19 diantaranya meninggal dunia. ${ }^{7}$ Ini menunjukkan bahwa tren tawuran antar pelajar secara nasional terus meningkat.

Keterpaduan antara pendidikan umum dan agama tersebut di atas diharapkan dapat memperbaiki keadaan dekadensi moral peserta didik akhir-akhir ini. Salah satu caranya melalui pengembangan dan optimalisasi kurikulum sekolah. Menurut Nata, ${ }^{8}$ konsep Islamisasi ilmu pengetahuan dapat terjadi oleh keterpaduan antara ilmu umum dan ilmu agama secara berimbang.

Dari permasalahan tersebut di atas, penulis memandang penting untuk melakukan penelitian lebih mendalam terkait terkait efektivitas pelaksanaan kurikulum terpadu di SMA Pesantren Terpadu Hayatan Thayyibah Kota Sukabumi.

\footnotetext{
4 Ahmad Tafsir, Filsafat Pendidikan Islami; Integrasi Jasmani, Rohani dan Kalbu Memanusiakan Manusia, (Bandung: Remaja Rosdakarya, 2010), 129.

5 Tafsir, Filsafat Pendidikan, 79-80. Tafsir, Ilmu Pendidikan, 41-46.

${ }^{6}$ http://lifestyle.kompas.com/read/2012/12/21/10534239/82.Pelajar tewas sia-sia karena tawuran. Diakses tanggal 04 Januari 2018.

${ }^{7}$ https://metro.tempo.co/read/531130/tawuran-sekolah-jakarta-naik-44-persen. Diakses tanggal 04 Januari 2018.

${ }^{8}$ Abuddin Nata, Manajemen Pendidikan; Mengatasi Kelemahan Pendidikan Islam di Indonesia, (Jakarta: Kencana, 2010), 99.
} 
Penelitian ini akan memfokuskan bahasannya untuk menjawab pertanyaan penelitian: Bagaimana Efektivitas Kurikulum Terpadu Berbasis Nilai-Nilai Islami yang dilaksanakan di SMA Pesantren Terpadu Hayatan Thayyibah Kota Sukabumi? dari pertanyaan inti tersebut peneliti merincinya dengan pertanyaan-pertanyaan sebagai berikut: (1) Bagaimana konsep kurikulum terpadu berbasis nilai-nilai Islami di SMA Pesantren Terpadu Hayatan Thayyibah Kota Sukabumi?, (2) Bagaimana implementasi kurikulum terpadu berbasis nilai-nilai Islami di SMA Pesantren Terpadu Hayatan Thayyibah Kota Sukabumi?, (3) Bagaimana evaluasi kurikulum terpadu berbasis nilainilai Islami di SMA Pesantren Terpadu Hayatan Thayyibah Kota Sukabumi?, (4) Apa faktor pendukung dan penghambat kurikulum terpadu berbasis nilai-nilai Islami di SMA Pesantren Terpadu Hayatan Thayyibah Kota Sukabumi?

\section{B. Teori / Konsep}

\section{Konsep Dasar Kurikulum}

Secara etimologi kurikulum berasal dari kata currir yang artinya berlari dan curere yang berarti tempat berpacu, keduanya merupakan kata dalam bahasa Yunani. ${ }^{9}$ Menurut Al-Khauly yang dikutip oleh Muhaimin kurikulum dalam bahasa Arab dimaknai dengan istilah Manhaj, yang artinya jalan terang yang dilalui oleh manusia pada bidang kehidupannya. Dalam kontek pendidikan, kurikulum berarti jalan terang yang dilalui oleh pendidik dengan peserta didik dalam rangka pengembangan pengetahuan, keterampilan, sikap dan nilai-nilai. Berupa seperangkat rencana dan media untuk mengantarkan lembaga pendidikan dalam mewujudkan tujuan pendidikan yang diinginkan. ${ }^{10}$

Dakir dalam bukunya Perencanaan dan Pengembangan Kurikulum menyatakan bahwa kurikulum adalah seperangkat program pendidikan yang didalamnya memuat berbagai bahan ajar dan pengalaman belajar, yang dirancangkan dan direncanakan secara sistemik atas dasar norma-norma yang berlaku yang oleh pendidik dan peserta didik dijadikan pedoman bersama dalam proses pembelajaran untuk mencapai tujuan pendidikan. ${ }^{11}$

Oemar Hamalik dalam bukunya Manajemen Pengembangan Kurikulum menyatakan bahwa kurikulum adalah program pendidikan yang dibuat oleh lembaga pendidikan untuk peserta didik. Berdasarkan program pendidikan tersebut, peserta didik melakukan berbagai kegiatan belajar sehingga mampu mendorong perkembangan dan pertumbuhan mereka sesuai dengan tujuan pendidikan yang telah ditetapkan. Secara lebih luas kurikulum bukan hanya kumpulan mata pelajaran-mata pelajaran, namun segala sesuatu yang dapat mempengaruhi perkembangan peserta didik, termasuk juga sarana dan prasarana yang berbentuk fisik. ${ }^{12}$

\footnotetext{
${ }_{9}^{9}$ Abdullah Idi, Pengembangan Kurikulum; Teori dan Praktik, (Yogyakarta: Ar-Ruzz Media, 2007), 183.

${ }^{10}$ Muhaimin, Pengembangan Kurikulum Pendidikan Agama Islam; di Sekolah, Madrasah, dan Perguruan Tinggi, (Jakarta: Raja Grafindo Persada, 2010), 1.

${ }^{11}$ Dakir, Perencanaan dan Pengembangan Kurikulum, (Jakarta: Rineka Cipta, 2010), 3.

12 Oemar Hamalik, Manajemen Pengembangan Kurikulum, (Bandung: Remaja Rosdakarya, 2007), 10.
} 
Sehingga dapat disimpulkan dari beberapa pengertian kurikulum di atas bahwa pertama, kurikulum memuat isi dan materi pelajaran, yaitu sejumlah mata ajaran (subject matter) yang harus ditempuh untuk memperoleh sejumlah pengetahuan. Kedua, kurikulum sebagai rencana pembelajaran, yaitu suatu program pendidikan yang disediakan untuk membelajarkan peserta didik. Ketiga, kurikulum sebagai pengalaman belajar, dimana proses belajar mengajar yang dikemas dalam kurikulum selain di dalam kelas, juga mencakup kegiatan-kegiatan dalam proses belajar mengajar di luar kelas. Maka pada hakikatnya kurikulum adalah semua kegiatan yang memberikan pengalaman belajar baik di dalam maupun luar kelas. ${ }^{13}$

Berorientasi pada pengertian kurikulum dalam arti luas, Hilda Taba dalam Zainal Arifin ${ }^{14}$ menjelaskan bahwa terdapat tiga fungsi kurikulum, yaitu:

a. Kurikulum sebagai transmisi, yakni berfungsi sebagai pewaris nilai-nilai kebudayaan.

b. Kurikulum sebagai transpormasi, yakni berfungsi sebagai rekonstruksi sosial.

c. Kurikulum sebagai pengembanagan individu.

Fungsi kurikulum identik dengan pengertian kurikulum yang berkaitan langsung dengan kegiatan pendidikan, maka fungsi kurikulum menurut Khaeruddin $\mathrm{dkk}^{15}$ adalah sebagai berikut:

a. Kurikulum sebagai acuan dalam penyelenggara pendidikan pada suatu tingkatan lembaga pendidikan.

b. Kurikulum sebagai batasan dari program kegiatan (bahan pelajaran) yang dibuat dan yang akan dijalankan pada suatu semester, kelas, maupun pada tingkat pendidikan tertentu.

c. Kurikulum sebagai acuan bagi guru dalam menyelenggarakan proses belajar mengajar, sehingga proses belajar yang dilakukan oleh pendidik dengan peserta didik menjadi terarah sesuai dengan tujuan yang ditentukan.

Abdullah Idi membagi jenis-jenis kurikulum kedalam empat, yaitu: ${ }^{16}$

\section{a. Separate Subject Curriculum}

Jenis ini merupakan bahan pelajaran yang disajikan dalam bentuk subject metter atau mata pelajaran yang terpisah-pisah, yang satu lepas dari yang lain. Maka konsekuensi yang harus diambil oleh peserta didik adalah jumlah banyak mata pelajaran yang sangat banyak. Subject metter atau mata pelajaran merupakan hasil

${ }^{13}$ Oemar Hamalik, Kurikulum dan Pembelajaran, (Jakarta: Bumi Aksara, 2013), 16-17.

${ }^{14}$ Zainal Arifin, Konsep dan Model Pengembangan Kurikulum, (Bandung: Remaja Rosdakarya, 2013), 12.

${ }^{15}$ Khaeruddin dkk, KTSP Konsep dan Implementasinya di Madrasah, (Jogjakarta: MDC Jawa Tengah dan Pilar Media, 2007), 28.

${ }^{16}$ Idi, Pengembangan Kurikulum, 115-122. Menurut Tim Pakar Manajemen Pendidikan UNM ada yang disebut Core Curriculum, yaitu kurikulum inti yang diberikan kepada semua peserta didik untuk mencapai keseluruhan program kurikulum secara utuh. Contoh di Indonesia adalah: Agama dan PPKn. Tim Pakar Manajemen Pendidikan UNM, Manajemen Pendidikan; Analisis Substantif dan Aplikasinya dalam Institusi Pendidikan, (Malang: Universitas Negeri Malang, 2003), 28. 
pengalaman manusia sepanjang sejarah, yang berupa pengetahuan dan kebudayaan yang dikumpulkan sejak dahulu, lalu disusun secara logis dan sitematis, disederhanakan dan disajikan kepada peserta didik yang disesuaikan dengan usianya masing-masing.

\section{b. Corelated Curriculum}

Jenis ini merupakan sekumpulan mata pelajaran dihubungkan antara yang satu dengan yang lain, sehingga ruang lingkup bahan yang tercakup semakin luas. Sebagai contoh, mata pelajaran Fikih dapat dihubungkan dengan mata pelajaran Al-Qur'an dan Hadist. Pada saat peserta didik mempelajari shalat, maka dapat dihubungkan dengan pelajaran Al-Qur'an (Surat Al-Fatihah, dan surat lainnya) dan hadist yang berhubungan dengan shalat.

\section{c. Broad Fields Curriculum}

Jenis kurikulum ini disebut juga kurikulum fusi, yaitu menghapuskan batas-batas dan menyatukan mata pelajaran yang berhubungan erat. Sebagai contoh: AlQur'an, Al-Hadist, Akidah akhlak, Fikih dan Sejarah Kebudayaan Islam disatukan menjadi Pendidikan Agama Islam.

\section{d. Integrated curriculum}

Jenis ini merupakan hasil dari usaha pengintegrasian materi ajar dari berbagai macam pelajaran. Integrasi diciptakan dengan memusatkan pelajaran pada masalah tertentu yang memerlukan solusi dengan materi berbagai disiplin ilmu atau mata pelajaran. Sehingga diharapkan akan membentuk peserta didik yang mempunyai pribadi yang terintegrasi.

\section{Kurikulum Terpadu}

Secara bahasa kurikulum terpadu mengandung arti perpaduan, koordinasi, harmoni, kebulatan, keseluruhan. Kurikulum ini menyajikan bahan pelajaran dalam bentuk unit atau keseluruhan dan meniadakan batas-batas antara berbagai mata pelajaran. Dengan kebulatan bahan pelajaran diharapkan peserta didik mempunyai pribadi yang integrated yakni manusia yang sesuai atau selaras hidupnya dengan lingkungan sekitarnya. ${ }^{17}$ Caswell menjelaskan sebagaimana dikutip oleh S. Nasution bahwa suatu unit mempunyai tujuan yang bermakna bagi peserta didik yang biasanya dituangkan dalam bentuk masalah. Untuk memecahkan masalah tersebut peserta didik melakukan serangkaian kegiatan yang saling berkaitan. Menghadapkan anak kepada masalah berarti merangsangnya untuk berfikir dan ia merasa tidak puas sebelum memecahkan masalah tersebut. ${ }^{18}$

\footnotetext{
${ }^{17}$ S. Nasution, Azas-azas Kurikulum, (Jakarta: Bumi Aksara, 2003), 176.

${ }^{18}$ Nasution, Azas-azas, 195.
} 
Pada perkembangan awal, konsep kurikulum terpadu hanya merupakan bagian dari kurikulum sebagai sebuah rencana, yakni sekedar sebuah bentuk desain materi pelajaran, seperti istilah: integration, correlation, interdisciplinary, unit, fusi, broad filed, dan lain-lain. Perkembangan selanjunya konsep kurikulum terpadu telah dipandang bukan hanya sekedar pengaturan materi pelajaran dan bagian dari perencanaan, tetapi telah menjadi suatu model konsep kurikulum yang memiliki konsep yang utuh (baik sebagai ide, rencana, proses maupun hasil). Kurikulum ini juga memiliki desain yang lebih lengkap mulai dari rumusan tujuan, materi, strategi pembelajaran, dan evaluasi. ${ }^{19}$

Forgarty dalam Syaifuddin Sabda mendefinisikan bahwa kurikulum terpadu sebagai suatu model kurikulum yang dapat mengintegrasikan skills, themes, concepts, and topics secara inter dan antar disiplin atau penggabungan keduanya. Lebih lanjut Syaifuddin Sabda mengutip pendapatnya Maurer mendefinisikan bahwa kurkulum terpadu adalah: "the organization and tarnfer of knowledge under a united or interdisciplinary theme". Selajutnya Beane dalam Syaifuddin Sabda mendefinisikan bahwa kurikulum terpadu adalah model kurikulum yang menawarkan sejumlah kemungkinan tentang kesatuan dan keterkaitan antara kegiatan sehari-hari dengan pengalaman di sekolah atau pengalaman pendidikan. ${ }^{20}$

Maurer dalam Syaifuddin Sabda menjelaskan enam unsur yang harus ada dalam sebuah desain kurikulum terpadu, yaitu: (1) tujuan umum (common objectives), (2) tema umum (common theme), (3) kerangka waktu (common time frame), (4) pola sequen materi (diverse sequencing pattern), (5) strategi aplikasi pembelajaran (applied learning strategies), dan (6) bentuk pengukuran (varied assessment). ${ }^{21}$

Raka Joni dalam Syaifuddin Sabda menjelaskan ada tiga tahapan atau langkah yang harus dilakukan dalam aspek dan prosedur implementasi kurikulum terpadu, diantaranya adalah: tahapan perencanaan, pelaksanaan, dan evaluasi. Berikut ini akan dikemukakan beberapa hal yang terkait dengan ketiga langkah tersebut.

\section{a. Perencanaan}

Perencanaan atau persiapan merupakan penyususnan sesuatu yang akan dilakukan untuk mencapai tujuan yang telah ditentukan. Secara umum aspekaspek yang perlu direncanakan dalam perencanaan implementasi kurikulum terpadu, sebagaimana yang dikemukakan oleh Maurer yang dikutip oleh Syifuddin Sabda diantaranya adalah: ${ }^{22}$ (a) rumusan tujuan umum (common objective), (b) penentuan tema umum (common theme), (c) penentuan kerangka waktu (common time frame), (d) bentuk pola sekuen materi (diverse sequening pattern), (e) model strategi aplikasi pembelajaran (applied learning strategies), dan (f) penetapan bentuk pengukuran (viaried assesment). Realisasi aspek-aspek tersebut dapat diwujudkan dalam bentuk perencanaan tertulis dan tidak tertulis.

\footnotetext{
${ }^{19}$ Syaifuddin Sabda, Model Kurikulum Terpadu IPTEK dan IMTAQ, (Ciputat: Ciputat Press Group, 2006), 27.

${ }^{20}$ Sabda, Model Kurikulum, 29-28.

${ }^{21}$ Sabda, Model Kurikulum, 61-62.

${ }^{22}$ Sabda, Model Kurikulum, 103.
} 


\section{b. Pelaksanaan}

Tahap pelaksanaan merupakan pelaksanaan kegiatan proses belajar mengajar, sebagai unsur inti dari aktivitas pembelajaran yang dalam pelaksanaannya disesuaikan dengan rambu-rambu yang telah disusun dalam perencanaan sebelumnya. Secara prosedural langkah-langkah kegiatan yang ditempuh diterapkan ke dalam tiga langkah, yaitu: kegiatan awal atau pembuka, kegiatan inti, dan kegiatan akhir atau penutup.

\section{c. Evaluasi}

Sebagai tahap terakhir dari kegiatan implementasi kurikulum dituntut adanya ketuntasan aktivitas dan keterukuran hasil yang dicapai, oleh karena itu pada tahap ini diperlukan adanya kegiatan evaluasi. Evaluasi adalah penentuan penilaian suatu program dan penentuan pencapaian tujuan suatu program. Penilaian merupakan suatu bentuk sistem pengujian dalam pembelajaran keterampilan untuk mengetahui seberapa jauh peserta didik telah menguasai kompetensi dasar yang dipilih dan diterapkan oleh guru dalam pembelajaran. Raka Joni berpendapat bahwa bentuk evaluasi dalam kurikulum terpadu pada hakikatnya tidak berbeda dengan bentuk evaluasi kurikulum konvensional, perbedaan dalam evaluasi kurikulum tepadu di samping evaluasi terhadap proses dan hasil namun juga harus banyak diarahkan pada evaluasi terhadap dampak pengiring (nurturane effects). ${ }^{23}$

\section{Lembaga Pendidikan Islam di Indonesia}

\section{a. Pondok Pesantren}

Menurut Dhofier ${ }^{24}$ secara termonologis Pondok Pesantren adalah lembaga pendidikan tradisional Islam untuk mempelajari, memahami, menghayati dan mengamalkan ajaran Islam dengan menekankan pentingnya moral keagamaan sebagai pedoman perilaku santri sehari-hari. Tim Penulis Departemen Agama ${ }^{25}$ dalam buku Pola Pembelajaran Pesantren mendefinisikan bahwa pondok pesantren adalah pendidikan dan pengajaran Islam dimana didalamnya terjadi interaksi antara kyai dan ustadz sebagai guru dan para santri sebagai murid dan mengambil tempat di masjid atau halaman-halaman pondok untuk mengkaji dan membahas buku-buku teks keagamaan karya ulama masa lalu. Dengan demikian, unsur terpenting bagi pesantren adalah adanya kyai, para santri, masjid, pondok serta literatur klasik/kitab kuning. Ensiklopedi Islam memberi gambaran berbeda, yakni bahwa pesantren itu berasal dari bahasa Tamil yang artinya guru ngaji, atau dari kata bahasa India 'shastri' dan kata 'shastra' yang berarti buku-buku suci, kitab-kitab agama atau ilmu tentang pengetahuan. ${ }^{26}$

\footnotetext{
${ }^{23}$ Sabda, Model Kurikulum, 107-108.

24 Zamakhsyari Dhofier, Tradisi Pesantren; Studi Pandangan Hidup Kyai dan Visinya Mengenai Masa Depan Indonesia, (Jakarta: LP3ES, 2011), 84.

25 Tim Penulis Departemen Agama, Pola Pembelajaran Pesantren, (Jakarta: 2003), 3.

${ }^{26}$ Hasan Shadily, Ensiklopedi Islam, (Jakarta: Ichtiar Baru Van Hoeve, 1993), 99.
} 
Sedangkan secara etimologis definisi sangat beragam dan variatif oleh para pakar. M. Arifin mendefinisikan pesantren sebagai suatu lembaga pendidikan agama Islam yang tumbuh dan diakui oleh masyarakat sekitar. Berbeda dengan Abdurrahman Wahid, yang memberikan definisi terhadap pesantren secara teknis sebagai a place where santri (student) live (suatu lembaga dimana seorang santri/murid tinggal). ${ }^{27}$ Pesantren adalah sebuah asrama pendidikan tradisional, dimana para siswanya semua tinggal bersama dan belajar dibawah bimbingan guru dan lebih dikenal dengan sebutan Kyai dan mempunyai asrama untuk tempat penginapan santri.(Manpan Drajat, 2015) Santri tersebut berada dalam komplek yang juga menyediakan masjid untuk beribadah, ruang untuk belajar dan kegiatan keagamaan lainnya. Komplek ini biasanya dikelilingi oleh tembok untuk dapat mengawasi keluar masuknya para santri sesuai dengan peraturan yang berlaku. ${ }^{28}$

Ada beberapa pembagian pondok pesantren berdasarkan tipologinya Menurut Yacub yang dikutip oleh Khozin, diantaranya adalah:

1) Pesantren Salafi

Pesantren jenis ini yaitu pesantren yang tetap mempertahankan pelajarannya dengan kitab-kitab klasik tanpa memberikan pengetahuan umum. Model pengajarannya sebagaimana yang lazim diterapkan yaitu dengan metode sorogan dan weton.

2) Pesantren Khalafi

Pesantren jenis ini yaitu pesantren yang menerapkan sistem pengajaran klasik (madrasah), dengan memberikan ilmu umum dan ilmu agama, serta memberikan pendidikan keterampilan.

3) Pesantren Kilat

Pesantren jenis ini yaitu pesantren yang berbentuk semacam training dalam waktu relatif singkat, dan biasanya dilaksanakan pada waktu libur sekolah. Pesantren ini menitikberatkan pada keterampilan ibadah dan kepemimpinan. Sedangkan santrinya sendiri terdir dari siswa sekolah yang dipandang perlu mengikuti kegiatan keagamaan dipesantren kilat.

4) Pesantren Terintegritas

Pesantren jenis ini yaitu pesantren yang lebih menekankan pada pendidikan vokasional atau kejuruan, sebagaimana balai latihan kerja Departemen Tenaga Kerja, dengan program yang terintegritas. Sedangkan santrinya mayoritas berasal dari kalangan anak putus sekolah atau para pencari kerja. $^{29}$

Sedangkan menurut Mas'ud dkk, ada beberapa tipologi atau model pondok pesantren yaitu:

\footnotetext{
${ }^{27}$ Ahmad Muthohar, Ideologi Pendidikan Pesantren, (Semarang: Pustaka Rizki Putra, 2007), 12.

${ }^{28}$ Dhofier, Tradisi Pesantren, 18.

${ }^{29}$ Khozin, Jejak-Jejak Pendidikan Islam di Indonesia, (Malang: UMM Press, 2006), 101.
} 
1) Pesantren yang mempertahankan kemurnian identitas aslinya sebagai tempat mendalami ilmu-ilmu agama (tafaqquh fiddin) bagi para santrinya. Semua materi yang diajarkan di pesantren ini sepenuhnya bersifat keagamaan yang bersumber dari kitab-kita berbahasa Arab (kitab kuning) yang ditulis oleh para ulama abad pertengahan. Pesantren model ini masih banyak kita jumpai hingga sekarang, seperti pesantren Lirboyo di Kediri jawa Timur, beberapa pesantren di daerah Sarang kabupaten Rembang, Jawa Tengah dan lain-lain.

2) Pesantren yang memasukkan materi-materi umum dalam pengajarannya, namun dengan kurikulum yang disusun sendiri menurut kebutuhan dan tidak mengikuti kurikulum yang ditetapkan pemerintah secara nasional sehingga ijazah yang dikeluarkan tidak mendapatkan pengakuan dari pemerintah sebagai ijazah formal.

3) Pesantren yang menyelenggarakan pendidikan umum di dalamnya, baik berbentuk madrasah (sekolah umum berciri khas Islam di bawah naungan Kementrian Agama) maupun Sekolah (sekolah umum di bawah Kementrian Pendidikan dan Kebudayaan) dalam berbagai jenjangnya, bahkan ada sampai Perguruan Tinggi yang tidak hanya meliputi fakultas-fakultas keagamaan melainkan fakultas-fakultas umum. Contohnya Pesantren Tebu Ireng di Jombang, Jawa Timur.

4) Pesantren yang merupakan asrama pelajar Islam dimana para santrinya belajar di sekolah-sekolah atau perguruan tinggi di luarnya. Pendidikan agama di pesantren model ini diberikan di luar jam-jam sekolah sehingga bisa diikuti oleh semua santrinya. Diperkirakan pesantren inilah yang terbanyak jumlahnya.

\section{b. Sekolah Berciri Khas Keagamaan (Islam)}

Pendirian sekolah Islam, adalah adopsi sistem pendidikan gubernemen Belanda, yang dipandang sebagai pendidikan karakter sekuler. Sekolah Islam berbeda dengan madrasah, sebab madrasah saat itu masih terpusat pada pendidikan agama, sedangkan sekolah Islam memadukan kurikulum antara pengetahuan agama dan umum dengan tujuan agar dengan upaya tersebut mampu mencurahkan dan memberdayakan umat Islam dalam memasuki era modern. ${ }^{30}$

Lembaga Pendidikan Islam yang didirikan tersebut dilatarbelakangi oleh permasalahan yang membelit umat Islam yang jauh dari nilai-nilai Islam dalam praktek kehidupannya, justru kebodohan, kemiskinan, dan keterbelakangan yang dialami umat Islam saat itu ingin dirintis oleh Ahmad dahlan. Sejak awal berdirinya organisasi Muhammadiyah merupakan gerakan purifikasi pemikiran Islam dan sekaligus memposisikan diri sebagai gerakan dakwah dan pendidikan.

${ }^{30}$ Tim Mutu JSIT, Standar Mutu Sekolah Islam Terpadu, (Jakarta: Jaringan Sekolah Islam Terpadu, 2010), 44-47. 
Muhammadiyah telah menetapkan bahwa pendirian sekolah itu dalam rangka mencapai tujuan organisasi yakni menegakan dan menjunjung tinggi agama Islam sehingga terwujud masyarakat Islam yang sebenar-benarnya. Selanjutnya rintisan tersebut diteruskan oleh yayasan-yayasan yang terus berdiri membangun negeri ini dengan sekolah-sekolah Islam sebagaimana tersebut di atas. Dalam perjalana panjang hingga era modern ini Sekolah Islam yang didirikan memiliki tujuan yang lebih bisa menyesuaikan diri dengan kemoderannya yakni mewujudkan sekolah Islam Unggulan, yang bisa membekali akhlak mulia dan tidak gagap teknologi.

Latar belakang lain dikemukakan oleh Karel A Steenbrink bahwa salah satu dorongan berdirinya sekolah Islam berasal dari kelompok pembaharuan pendidikan Islam. Karena cukup banyak orang dan organisasi Islam yang tidak puas dengan metode tradisional dalam mempelajari Al-Quran dan Sunnah. Mereka berusaha memperbaiki pendidikan Islam dari sisi matode maupun isi serta mengusahakan kemungkinan memberikan pendidikan umum untuk orang Islam. ${ }^{31}$ Kelompok pembaharu tersebut bernama Persyarikatan Muhammadiyah, yang dalam perjalanan seabad itu telah mewarnai dan mempengaruhi sistem pendidikan nasional di Indonesia.

Menurut Abdurrahman An-Nahlawi bahwa kurikulum pendidikan Islam harus memiliki sifat dan karakteristiknya yang Islami, yakni mengacu pada dasar pemikiran yang Islami serta bertolak dari pandangan hidup serta pandangan tentang manusia serta diarahkan kepada tujuan pendidikan yang dilandasi kaidahkaidah Islami. ${ }^{32}$ Untuk itu kurikulum Islami harus memenuhi kriteria sebagai berikut:

1) Sistem dan perkembangan kurikulum harus selaras denga fitrah manusia.

2) Kurikulum hendaknya diarahkan untuk mencapai tujuan akhir Pendidikan Islam, yakni: ikhlas, taat, dan beribadah kepada Allah.

3) Pentahapan serta pengkhususan kurikulum harus memperhatikan tahapantahapan perkembangan peserta didik dan kekhasannya.

4) Dalam berbagai pelaksanaan, aktivitas, contoh dan nashnya, hendaknya kurikulum memelihara segala kebutuhan nyata kehidupan masyarakat, sambil tetap bertopang pada jiwa dan cita ideal Islaminya.

5) Secara keseluruhan struktur dan organisasi kurikulum tidak kontroversi dan terarah pada pola hidup Islami.

6) Kurikulum itu hendaknya realistik artinya dapat dilaksanakan sesuai dengan situasi dan kondisi setempat.

7) Hendaknya kurikulum itu efektif artinya menyampaikan dan menggugah perangkat nilai edukatif yang membuahkan tingkah laku positif dan nilai efektif yang positif pada jiwa manusia.

\footnotetext{
${ }^{31}$ Karel A. Steenbrink, Pesantren, Madrasah, Sekolah: Pendidikan Islam dalam Kurun Modern, (Jakarta: LP3ES ), 26-27.

32 Abdurrahman An-Nahlawi, Prinsip-prinsip dan Metode Pendidikan Islam dalam Keluarga, Sekolah dan Masyarakat, (Bandung: CV Diponegoro, 1989), 269-275.
} 
8) Hendaknya kurikulum memperhatikan tingkat perkembangan siswa. Kurikulum hendaknya memperhatikan aspek-aspek tingkah laku amaliah Islami.

\section{Metode Penelitian}

Penelitian ini menggunakan pendekatan kualitatif yang bertujuan untuk memahami fenomena-fenomena sosial dari perspektif partisipan, yang diperoleh melalui pengamatan partisipatif dalam kehidupan orang-orang yang menjadi partisipan. ${ }^{33}$ yaitu dengan cara mendeskripsikan dan menganalisa pada kajian efektivitas kurikulum terpadu yang diterapkan di SMA Pesantren Terpadu Hayatan Thayyibah Kota Sukabumi yang berlandaskan pada nilai-nilai Islami. Dalam penelitian ini penulis melakukan penelitian dengan cara mengamati, menganalisa, dan mendeskripsikan konsep kurikulum terpadu, implementasi kurikulum terpadu, evaluasi kurikulum terpadu, hasil kurikulum terpadu, serta faktor pendukung dan penghambat kurikulum terpadu pada sekolah yang berbasis pada pengembangan nilai-nilai Islami.

Adapun metode yang digunakan dalam penelitian ini bersifat deskriptif kualitatif. Penelitian deskriptif adalah suatu metode penelitian yang ditujukan untuk menggambarkan fenomena-fenomena yang ada, yang berlangsung pada saat ini atau sudah lampau. Penelitian ini menggambarkan kondisi apa adanya. ${ }^{34}$ Semenatara penelitian kualitatif menurut Bogdan dan Taylor, adalah sebuah prosedur penelitian yang menghasilkan data deskriptif berupa kata-kata tertulis atau lisan dari orang-orang dan perilaku yang dapat diamati. ${ }^{35}$ Maka dalam penelitian ini metode deskriptif kualitatif bertujuan untuk mengeksplor, mendeskripsikan, dan menganalisa bagaimana konsep, implementasi, evaluasi, serta faktor pendukung dan penghambat pada efektivitas kurikulum terpadu berbasis nilai-nilai Islami di SMA Pesantren Terpadu Hayatan Thayyibah Kota Sukabumi.

\section{Kurikulum Terpadu Berbasis Nilai-Nilai Islami}

\section{Konsep Kurikulum Terpadu Berbasis Nilai-Nilai Islami}

SMA Pesantren Terpadu Hayatan Thayyibah Kota Sukabumi memiliki visi "unggul dalam iman dan taqwa, terdepan dalam ilmu pengetahuan dan teknologi menuju sekolah bertaraf internasional." Serta memiliki misi di bawah ini:

a. Meningkatkan kemampuan membaca, memahami dan mengamalkan AlQur'an dan Sunnah Nabawiyyah.

b. Meningkatkan kemampuan penguasaan Ilmu Pengetahuan dan Teknologi.

c. Membudayakan penggunaan Bahasa Asing.

d. Mengkondisikan Sekolah sebagai komunitas Pesantren berwawasan global.

e. Melaksanakan proses Belajar Mengajar berbasis Teknologi dan Informasi.

\footnotetext{
${ }^{33}$ Emzir, Metodologi Penelitian Pendidikan: Kuntitatif dan Kualitatif, (Jakarta: PT Raja Grafindo Persada, 2008) 28.

${ }^{34}$ Nana Syaodih Sukmadinata, Metode Penelitian Pendidikan, (Bandung: Remaja Rosdakarya, 2013), 54.

${ }^{35}$ Lexy J. Moleong, Metodologi Penelitian Kualitatif, (Bandung: Remaja Rosdakarya, 2010), 4.
} 
Untuk mewujudkan visi dan misi tersebut di atas, SMA Pesantren Terpadu Hayatan Thayyibah Kota Sukabumi mengembangkan kurikulum terpadu berbasis nilai-nilai keislaman yang unik, yakni sebagai sekolah umum yang meramu kurikulumnya seratus persen dari Kemendikbud dengan kurikulum pesantren sebagai ciri khas sekolah ini.

Kurikulum umumnya menggunakan kurikulum nasional, yakni kurikulum dua ribu tiga belas ditambah dengan mata pelajaran-mata pelajaran yang akan dilombakan. Sedangkan kurikulum kepesantrenan menggunakan mata pelajaran yang hampir mirip dengan Kurikulum Depag, namun rujukannya disadur dari kitab klasik yang materinya disesuaikan dengan kebutuhan praktis peserta didik. Mata pelajaran ini masuk jadwal harian mata pelajaran sekolah, seperti Al-Qur'an Hadist, Akidah Akhlaq, Sejarah Kebudayaan Islam (SKI), Fiqh, dan Nahwu Sharaf. Khusus untuk peserta didik yang tinggal di asrama (boarding school) kajian kitab dilaksanakan sehabis subuh, sedangkan untuk peserta didik yang full day school kajian kitabnya dilaksanakan pada hari sabtu dalam format pengajian umum (stadium general).

\section{Implementasi Kurikulum Terpadu Berbasis Nilai-Nilai Islami}

Implementasi kurikulum terpadu yang dikembangkan dan dilaksanakan di SMA Pesantren Terpadu Hayatan Thayyibah Kota Sukabumi secara garis besar menggunakan dua kurikulum, yaitu:

\section{a. Kurikulum Nasioanal}

Kurikulum Nasional (Kurikulum Dua Ribu Tiga Belas) seperti mata Pelajaran Pendidikan Agama Islam (PAI) dan mata pelajaran-mata pelajaran yang lainnya dengan menambahkan sejumlah mata pelajaran yang akan di olimpiadekan seperti Matematika olimpiade, Geografi olimpiade, dan Astronomi. Mata pelajaran-mata pelajaran tambahan ini masuk dalam jadwal harian mata pelajaran sekolah. Ini merupakan bagian dari pengembangan kurikulum dimana pemerintah memberikan keleluasaan bagi sekolah swasta untuk mengembangakannya sesuai dengan kebutuhan peserta didik.

\section{b. Kurikulum Kepesantrenan}

Kurikulum Kepesantrenan yang dikembangkan oleh sekolah sendiri sebagai ciri khas dari lembaga ini. Kurikulum ini dikembangkan dalam bentuk mata pelajaran rumpun Agama yang dipecah kedalam beberapa mata pelajaran yang mirip dengan rumpun mata pelajaran yang ada di Madrasah Aliyah (Departemen Agama), yakni: Al-Qur'an Hadist, Akidah Akhlaq, Sejarah Kebudayaan Islam (SKI), Fiqh ditambah dengan Nahwu Sharaf, namun rujukan materinya diambil dari kitab klasik yang disesuaikan dengan kebutuhan praktis peserta didik. Sebagai contoh dalam mata pelajaran fiqh dalam kaifiyat pemulasaraan jenazah rujukannnya diambil dari kitab safitunnajah, namun tidak dipelajari secara 
keseluruhan bab demi bab yang ada dalam kitab tersebut, melainkan materi yang terkait dengan kebutuhan peserta didik saja.

\section{c. Muatan lokal}

Muatan lokal di sekolah ini adalah program character building yang didalamnya merupakan mata pelajaran Tahsin dan Tahfidz Al-qur'an yang dipandang sebagai penguatan dari nilai-nilai Islami yang dilaksanakan di sekolah ini. Dumulai dari proses placement test bagi peserta didik baru, apakah sudah baik dan benar membaca Al-qur'annya atau belum, secara garis besar yang belum lancar masuk program Tahsin (perbaikan bacaan Al-qur'an) yang sudah lancar masuk program Tahfidz (proses hafalan Al-qur'an). Target sekolah bagi yang belum lancar bacaannya selama mengikuti pembelajaran Tahsin diharapakan peserta didik dapat menguasai bacaan Al-qur'an sesuai dengan kaidah ilmu Tajwid. Apabila sudah baik dan benar bacaannya maka dilanjutkan ke program Tahfidz untuk proses menghafal Al-qur'an sesuai dengan target dan disesuaikan dengan kemampuan peserta didiknya. Sedangkan bagi yang sudah lancar bacaanya dan masuk kelas Tahfidz maka target sekolah selama tiga tahun peserta didik diharapkan mampu menghafal minimal tiga juz Al-Qur'an. Program Tahsin Tahfidz ini dilaksanakan setiap pagi sebelum kegiatan belajar mengajar dimulai, untuk kegiatan tambahan dilaksanakan setelah shalat Ashar bagi peserta didik yang memilih kegiatan ekstra kurikuler Tahsin Tahfidz, adapun untuk peserta didik yang tinggal di asrama (boarding school) kegiatan Tahsin Tahfidz ini dilaksankan kembali sehahis Shalat Magrib sampai Isya sebagai penguatan dari kurikulum kepesantrenan. Juga ada mulok Bahasa Daerah dalam hal ini adalah Bahasa Sunda.

\section{d. Pengembangan bahasa}

Pengembangan bahasa terdiri dari Bahasa Jerman, Bahasa Jepang, Bahasa Inggis dan Arab, khusus untuk ketiga dan keempat terakhir selain menjadi mata pelajaran reguler di kelas juga dijadikan program tambahan berupa pengayaan. Dalam Bahasa Inggris ada program conversation yang dilaksanakan sehabis Shalat Ashar, sedangkan untuk Bahasa Arab program Muhadatsah yang dilaksanakan Hari Senin dan Sabtu sehabis Shalat Subuh. Untuk kegiatan latihan ceramah ada program Muhadhoroh baik dalam Bahasa Inggris maupun Bahasa Arab yang dilaksanakan setiap Kamis malam.

\section{e. Program pembiasaan}

Program pembiasaan yang terangkum dalam delapan kebiasaan santri SMA Pesantren Terpadu Hayatan Thayyibah Koata Sukabumi, salah satunya adalah melaksanakan shalat fardhu secara berjama'ah, apabila kehadiran peserta didik dalam melaksanakan shalat berjama'ah kurang dari $75 \%$ maka orang tua yang bersangkutan akan dipanggil untuk diberikan peringatan awal. Karena shalat 
berjama'ah ini dijadikan prasyarat bagi peserta didik untuk dapat mengikuti ujian-ujian baik umum maupun kepesantrenan, batas untuk dapat mengikuti peserta didik diwajibkan minimal mengikuti shalat berjam'ah sebanyak $85 \%$. Program pembiasaan yang lainnya adalah Tilawah satu juz per hari, Shaum Senin Kamis, Shalat Tahajud, Shalat Dhula, Dawam Wudlu, Shodaqoh, Salam dan Sapa.

\section{f. Program ekstra kurikuler}

Ada dua program ekstra kurikulur yang wajib diikuti oleh peserta didik di sekolah ini yatu Pramuka yang dilaksanakan setiap hari Kamis sore dan Pencak Silat Tenaga Dalam (PSTD) yang dilaksankan setiap hari Jum'at sore, sedangkan yang lainnya diperbolehkan untuk memilih salah satunya, diantaranya adalah: Karya Ilmiah Remaja, Bahasa Jepang, Bahasa Jerman, Bahasa Inggris, Bola Basket, Futsal, Badminton, Bola Volly, Tenis Meja, Panahan, Marawis, Fotografi. Program ekstra kurikuler ini dilaksanakan setiap sore dari pukul 16.00 samapi dengan pukul 17.20 disesuaikan dengan jadwal pilihan masing-masing.

\section{Evaluasi Kurikulum Terpadu Berbasis Nilai-Nilai Islami}

Kepala sekolah sebagai manager mengadakan supervisi secara berkelanjutan dengan mengumpulkan seluruh civita akademika sekolah ini, mulai dari guru, karyawan, tata usaha, sampai petugas kebersihan dan satpam. Tujuan untuk menyamakan persepsi tentang program yang digulirkan pihak sekolah. Dalam hal pengembangan kurikulum kepala sekolah menanyakan secara langsung sejauh mana program kurikulum yang dicanangkan oleh sekolah dapat terealisasi. Apabila sudah terlaksana dengan baik maka dijadikan barometer untuk kedepannya, sedangkan ketika menemukan kendala dalam penerapannya dilapangan maka dicarikan solusi bersama-sama. Ini dilakukan minimal dalam satu bulan satu kali tepatnya hari senin sesudah pelaksanaan upacara bendera, bahkan lebih disesuaikan dengan kebutuhan.

Sementara waka kurikulum melakukan evaluasi kurikulum terpadu ini lebih kepada teknis di lapangan, sejauh materi yang diajarkan oleh guru sesuai atau tidaknya dengan ujian-ujian yang dilaksanakan oleh guru bersangkutan. Jadi guru sebelum melakukan penilaian baik ulangan harian, Penilaian Tengah Semester (PTS), maupun Penilaian Akhir Semester (PAS) diwajibkan untuk memberikan kisikisi terlebih dahulu.

Sedangkan kepala asrama melakukan evaluasi kurikulum ini melalui berbagai tahap, diantaranya: untuk penilaian akhlaknnya melalui observasi harian, untuk materi hafalan seperti Tahfidz Al-Qur'an dilaksanakan ujian lisan, untuk materi kaifiyat ibadah dilaksanakan melalui ujian praktek (demonstrasi) yang nantinya dijadikan akumulasi penilaian jangka pendek, menengah dan jangka panjang. 


\section{Faktor Pendukung dan Penghambat Kurikulum Terpadu Berbasis Nilai-Nilai Islami}

a. Faktor pendukung

1) Fasilitas kelas yg memadai karena sekolah sudah dilengkapi dengan wifi, setiap kelas dilengkapi proyektor dan TV yang terkoneksi dengan internet, sistem pembelajaran yang dirancang kreatif dan menyenangkan berbasis teknologi. Ini merupakan salah satu faktor kenyamanan peserta didik, sehingga mereka menyalurkan kecerdasan, bakat dan minatnya secara optimal dapat terlihat dari kejuaraan-kejuaran yang diperoleh peserta didik baik tingkat Kota, Provinsi, Nasional bahkan Internasional.

2) Keadaan sumber daya manusia yang mudah diajak kerjasama untuk memajukan pendidikan di sekolah ini. Karena pada dasarnya lembaga ini memberikan ruang kepada guru untuk mengeksplor kemampuannya. Berdasarkan wawancara dengan sejumlah peserta didik ${ }^{36}$ bahwa guru-gurunya sangat kompetennya dibidanngya, pemaparannya mudah dimengerti, dan sangat bersahabat dengan peserta didik.

3) Manajemen sekolah yang terlaksana dengan baik. Berdasarkan hasil penelitian terlihat bahwa roda menejerial sekolah berjalan dengan lancar, ditandai dengan antusiasme guru dalam melaksanakan pembelajaran secara all out dan penuh tanggung jawab.

\section{b. Faktor penghambat}

1) Ketidaksiapan sumber daya manusia (stake holder sekolah) untuk menjalankan program yang sudah dicanangkan oleh sekolah, dalam hal ini masih ada guru dan karyawan sekolah yang belum sepenuhnya menjalankan tanggung jawab dan kewajibannya dalam mencapai target pelaksanan kurikulum di sekolah ini.

2) Komunikasi dengan orangtua yang relatif masih kurang. Karena hasil dari penelitian pihak sekolah belum mengadakan acara secara khusus mengundang orang tua/wali murid untuk duduk bersama dalam membicarakan perkembangan peserta didik secara reguler.

3) Masih kurangnya waktu untuk melaksanakan proses pembelajaran secara ideal padahal struktur kurikulum sekolah sudah gemuk karena jumlah mata pelajaran yang banyak, implikasinya peserta didik sangat jenuh dan lelah sehingga untuk mengatasi masalah ini pihak sekolah mengadakan salah satunya dengan rihlah spiritual atau mukhoyyam Al-Qur'an.

4) Guru relatif tidak menguasai keilmuan secara komprehensif, sebatas parsial pada mata pelajaran yang diampunya. Bahkan masih ditemukan guru yang belum sesuai dengan antara kompetensi dengan mata pelajaran yang diampunya.

\footnotetext{
${ }^{36}$ Reza Mauludin, Wawancara pada hari Kamis, 02-08-2018. 08.30 WIB. M. Sulthan Fahri, Wawancara pada hari Kamis, 02-08-2018. 09.00 WIB. Syifa Mutiara Alifah, Wawancara pada hari Kamis, 02-082018. 09.30 WIB.
} 


\section{E. Penutup}

Berdasarkan pada hasil penelitian serta pembahasan tentang kurikulum terpadu berbasis nilai-nilai islami yang dilakukan peneliti di SMA Pesantren Terpadu Hayatan Thayyibah Kota Sukabumi, maka dapat dijabarkan simpulan penelitian sebagai berikut:

1. Konsep kurikulum terpadu yang dirumuskan oleh SMA Pesantren Terpadu Hayatan Thayyibah Kota Sukabumi mengintegrasikan kurikulum umum dan kepesantrenan, yang saling mempengaruhi (correlated curriculum), namun pada prakteknya dalam proses pembelajaran menggunakan mata pelajaran terpisah satu dengan yang lainnya (separate subject curriculum).

2. Implementasi kurikulum terpadu yang dikembangkan dan dilaksanakan di SMA Pesantren Terpadu Hayatan Thayyibah Kota Sukabumi kurikulum umumnya menggunakan kurikulum nasioanal (kurtilas) dengan menambahkan sejumlah mata pelajaran yang akan diolimpiadekan, dengan Kurikulum Kepesantrenan yang dikembangkan dalam bentuk mata pelajaran rumpun Agama yang dipecah kedalam beberapa mata pelajaran dengan rujukan materinya diambil dari kitab klasik yang disesuaikan dengan kebutuhan praktis peserta didik. Materi keagamaan dikembangkan dalam bentuk muatan lokal berupa program character building (Tahsin dan Tahfidz Al-qur'an dan program pembiasaan berupa Shalat Fardhu berjama'ah, Tilawah satu juz per hari, Shaum Senin Kamis, Shalat Tahajud, Shalat Dhula, Dawam Wudlu, Shodaqoh, Salam dan Sapa)

3. Evaluasi kurikulum terpadu yang dilaksanakan di SMA Pesantren Terpadu Hayatan Thayyibah Kota Sukabum, berjenjang mulai dari kepala sekolah yang bertugas mengevaluasi program yang telah dicanangkan secara berkelanjutan untuk melakukan perbaikan-perbaikan kedepan. Waka kurikulum melakukan evaluasi pada tataran teknis di lapangan. Kepala asrama melakukan evaluasi dengan cara menilai akhlak peserta didik melalui observasi harian, ujian lisan, ujian praktek (demonstrasi) yang dijadikan akumulasi penilaian jangka pendek, menengah dan jangka panjang.

4. Faktor pendukung dan penghambat penerapan kurikulum terpadu di SMA Pesantren Terpadu Hayatan Thayyibah Kota Sukabumi. Faktor pendukungnya adalah fasilitas pembelajaran yang memadai, keadaan sumber daya manusia yang mudah diajak kerjasama, manajemen sekolah yang terlaksana dengan baik sehingga guru dalam melaksanakan kegiatan pembelajaran secara all out dan penuh tanggung jawab. Adapaun faktor penghambatnya adalah ketidaksiapan sumber daya manusia (stake holder sekolah) untuk menjalankan program yang sudah dicanangkan oleh sekolah, komunikasi dengan orangtua yang relatif masih kurang, struktur kurikulum sekolah gemuk karena jumlah mata pelajaran yang banyak, masih ada guru yang belum sesuai dengan kompetensi dengan mata pelajaran yang diampunya. 


\section{DAFTAR PUSTAKA}

A. Steenbrink, Karel. Pesantren, Madrasah, Sekolah; Pendidikan Islam dalam Kurun Modern. Jakarta: LP3ES.

An-Nahlawi, Abdurrahman. Prinsip-prinsip dan Metode Pendidikan Islam dalam Keluarga, Sekolah dan Masyarakat. Bandung: CV Diponegoro, 1989.

Arifin, Zainal. Konsep dan Model Pengembangan Kurikulum. Bandung: Remaja Rosdakarya, 2013.

Dakir. Perencanaan dan Pengembangan Kurikulum. Jakarta: Rineka Cipta, 2010.

Dhofier, Zamakhsyari. Tradisi Pesantren; Studi Pandangan Hidup Kyai dan Visinya Mengenai Masa Depan Indonesia. Jakarta: LP3ES, 2011.

Emzir. Metodologi Penelitian Pendidikan: Kuntitatif dan Kualitatif. Jakarta: Raja Grafindo Persada, 2008.

Hamalik, Oemar. Kurikulum dan Pembelajaran. Jakarta: Bumi Aksara, 2013.

Hamalik, Oemar. Manajemen Pengembangan Kurikulum. Bandung: Remaja Rosdakarya, 2007.

http://lifestyle.kompas.com/read/2012/12/21/10534239/82. Pelajar tewas sia-sia karena tawuran. Di akses tanggal 04 Januari 2018.

https://metro.tempo.co/read/531130/tawuran-sekolah-jakarta-naik-44-persen. Di akses tanggal 04 Januari 2018.

Idi, Abdullah. Pengembangan Kurikulum; Teori dan Praktik. Yogyakarta: Ar-Ruzz Media, 2007.

Khaeruddin dkk. KTSP Konsep dan Implementasinya di Madrasah. Jogjakarta: MDC Jawa Tengah dan Pilar Media, 2007.

Khozin. Jejak-Jejak Pendidikan Islam di Indonesia. Malang: UMM Press, 2006.

Manpan Drajat, M. R. E. (2015). Etika Ptrofesi Guru. Alfabeta.

Effendi, M. Ridwan dan Manpan Drajat. Etika Profesi Guru. Cet. I: Bandung; Alfabeta, 2014.

Moleong, Lexy J. Metodologi Penelitian Kualitatif. Bandung: Remaja Rosdakarya, 2010.

Muhaimin. Pengembangan Kurikulum Pendidikan Agama Islam; di Sekolah, Madrasah, dan Perguruan Tinggi. Jakarta: Raja Grafindo Persada, 2010.

Muthohar, Ahmad. Ideologi Pendidikan Pesantren. Semarang: Pustaka Rizki Putra, 2007.

Nata, Abuddin. Kapita Selekta Pendidikan Islam; Isu-isu Kontemporer tentang Pendidikan Islam. Jakarta: Rajawali Pers, 2012.

Nata, Abuddin. Manajemen Pendidikan; Mengatasi Kelemahan Pendidikan Islam di Indonesia. Jakarta: Kencana, 2010.

Nasution, S. Azas-azas Kurikulum. Jakarta: Bumi Aksara, 2003.

Sabda, Syaifuddin. Model Kurikulum Terpadu IPTEK dan IMTAQ. Ciputat: Ciputat Press Group, 2006.

Shadily, Hasan. Ensiklopedi Islam. Jakarta: Ichtiar Baru Van Hoeve, 1993.

Sukmadinata, Nana Syaodih. Metode Penelitian pendidikan. Bandung: Remaja Rosdakarya, 2013.

Sukmadinata, Nana Syaodih dan R. Ibrahim. Teori Kurikulum dalam Ilmu dan Aplikasi Pendidikan; Bagaian I Ilmu Pendidikan Teoretis. Bandung: Tim Pengembang Ilmu Pendidikan, FIP UPI, 2009.

Tafsir, Ahmad. Filsafat Pendidikan Islami; Integrasi Jasmani, Rohani dan Kalbu Memanusiakan Manusia. Bandung: Remaja Rosdakarya, 2010.

Tafsir, Ahmad. Ilmu Pendidikan Perspektif Islam. Bandung: Remaja Rosdakarya, 2010. 
Tim Mutu JSIT. Standar Mutu Sekolah Islam Terpadu. Jakarta: Jaringan Sekolah Islam Terpadu, 2010.

Tim Pakar Manajemen Pendidikan UNM. Manajemen Pendidikan; Analisis Substantif dan Aplikasinya dalam Institusi Pendidikan. Malang: Universitas Negeri Malang, 2003.

Tim Penulis Departemen Agama. Pola Pembelajaran Pesantren. Jakarta: 2003. 